\title{
Kornelia Muss
}

SKLEJKA-EKO SA, Ostrów Wielkopolski

e-mail:kornelia.muss@gmail.com

\section{Tomasz Lesiów}

Uniwersytet Ekonomiczny we Wrocławiu

e-mail: tomasz.lesiow@ue.wroc.pl

ORCID: 0000-0002-1284-5874

\section{SYSTEM WCZESNEGO OSTRZEGANIA \\ PRZED NIEBEZPIECZNYMI ZANIECZYSZCZENIAMI \\ ŻYWNOŚCI: BIOLOGICZNYMI, ORGANICZNYMI \\ I/LUB NIEORGANICZNYMI ZWIĄZKAMI \\ CHEMICZNYMI ORAZ PRZECIWDZIALANIE \\ FALSZOWANIU ŻYWNOŚCI}

\author{
THE EARLY WARNING SYSTEM AGAINST \\ DANGEROUS CONTAMINATION \\ OF FOOD BY VARIETY OF BIOLOGICAL, ORGANIC \\ AND/OR INORGANIC CHEMICAL COMPOUNDS \\ AND PREVENTION OF FOOD ADULTERATION
}

DOI: $10.15611 /$ nit.2018.2.03

JEL Classification: Q19

Streszczenie: W celu ochrony żywności i/lub zagwarantowania jej bezpieczeństwa na rynku Unii Europejskiej utworzono System Wczesnego Ostrzegania o Niebezpiecznej Żywności i Paszach (RASFF). System ten służy do wymiany informacji związanych z zagrożeniami wykrytymi w żywności, paszach i/lub w materiałach przeznaczonych do kontaktu z produktami żywnościowymi. Każde państwo członkowskie w ramach tego systemu posiada krajowe punkty kontaktowe, odpowiedzialne za wymianę informacji z Komisją Europejską. Dzięki przesyłanym powiadomieniom członkowie systemów mogą na bieżąco kontrolować, w jakim produkcie wykryto zagrożenie i jakie działania należy podjąć, aby wyeliminować potencjalne ryzyko. W niniejszym opracowaniu zaprezentowano problematykę bezpieczeństwa konsumentów w odniesieniu do produktów żywnościowych oferowanych na jednolitym rynku Unii Europejskiej. Jego celem były przedstawienie sposobu funkcjonowania systemu RASFF oraz analiza powiadomień i ocena problemu występujących zagrożeń.

Słowa kluczowe: RASFF, raporty, zagrożenia, bezpieczeństwo żywności, fałszowanie żywności. 


\begin{abstract}
Summary: Technological progress, the development of the common market of the European Union and free movement of goods, increase the risk of contamination of food by various undesired organic or inorganic chemical compounds and/or by biological compounds such as pathogenic bacteria, both dangerous for the consumer health and in extreme cases for their life. In order to protect the food safety on EU common market the Rapid Alert System for Food and Feed (RASFF) was created. The RASFF system is used to exchange information related to threats detected in food, animal feed or materials intended to come into contact with food products. Each member state in the framework of the system has a National Contact Points responsible for the exchange of information with the European Commission. Thanks to sending the notifications, system members can keep control in which product threat was detected and what actions should be taken to eliminate the risk. This work takes the issue of safety of consumers regarding the products offered in the single market of the European Union. The aim of this study is to present how the RASFF system works and to analyze notifications and assess the problem of existing threats.
\end{abstract}

Keywords: RASFF, reports, danger, food safety, food adulteration.

\title{
1. Wstęp
}

W ciągu ostatnich lat zaobserwowano zwiększenie się wiedzy wśród konsumentów w odniesieniu do istniejących oraz potencjalnych zagrożeń, jakie może wywoływać żywność. Dlatego też coraz częściej podejmowane są działania mające na celu kontrolę przebiegu całego łańcucha żywnościowego. Bezpieczeństwo znacznie zróżnicowanego asortymentu żywności wprowadzanej na rynek jest dużym wyzwaniem nie tylko dla sektora żywnościowego, ale również dla organów rządowych. Dynamiczny rozwój globalnego rynku, swobodny przepływ towarów oraz zintensyfikowanie postępu technologicznego w sferze produkcji niewątpliwie zwiększają ryzyko pojawienia się produktów niespełniających standardowych normatywów dotyczących jakości i bezpieczeństwa. Niemożliwe jest jednak wprowadzenie ustawodawstwa w odniesieniu do każdego już istniejącego produktu lub produktu, który jeszcze nie został wprowadzony na rynek albo jest $\mathrm{w}$ trakcie opracowania technologii. W związku z tym Wspólnota opracowała uniwersalne zasady zawarte w Dyrektywie 2001/95/WE Parlamentu Europejskiego i Rady z dnia 3 grudnia 2001 r. w sprawie ogólnego bezpieczeństwa produktów [Adamczyk 2014; Dyrektywa 2001/95/WE]. Dyrektywa 2001/95/WE wprowadza uniwersalne wymagania bezpieczeństwa wobec wszystkich produktów oferowanych konsumentom, jednak nie eliminuje w pełni powstawania zagrożeń. Dlatego też konieczne stało się zapewnienie właściwego mechanizmu umożliwiającego wykrywanie niebezpieczeństwa, informowanie o nim oraz podejmowanie środków zapobiegawczych w całej Wspólnocie. Do takich mechanizmów zalicza się system RASFF - Rapid Alert System of Food and Feed, który służy do wymiany informacji związanych z zagrożeniami wykrytymi w żywności, paszach lub materiałach przeznaczonych do kontaktu z wyrobami żywnościowymi. Zasady funkcjonowania RASFF określa rozporządzenie Komisji (UE) nr 16/2011 
z dnia 10 stycznia 2011 r., ustanawiające środki wykonawcze dla systemu wczesnego ostrzegania o niebezpiecznych produktach żywnościowych i środkach żywienia zwierząt [Rozporządzenie Komisji (UE) nr 16/2011].

Celem niniejszego opracowania było przedstawienie problematyki bezpieczeństwa konsumentów w odniesieniu do produktów żywnościowych oferowanych na jednolitym rynku Unii Europejskiej, a także ukazanie sposobu funkcjonowania systemu RASFF oraz analiza powiadomień i ocena problemu występujących zagrożeń. W opracowaniu wykorzystano literaturę przedmiotu odnoszącego się do bezpieczeństwa żywności i produktów konsumpcyjnych, a informacje potrzebne do przeprowadzenia analizy zaczerpnięto $\mathrm{z}$ danych dostępnych na stronie internetowej Komisji Europejskiej. Pomocne okazały się również akty prawne dotyczące bezpieczeństwa wyrobów zarówno żywnościowych, jak i nieżywnościowych.

\section{Zagrożenia żywności}

Potrzeba bezpieczeństwa znajduje się na drugim poziomie piramidy Maslowa. Oznacza to, że zaraz po zaspokojeniu potrzeb fizjologicznych pojawiają się potrzeby związane z poczuciem bezpieczeństwa zarówno ekonomicznego, fizycznego, jak i zdrowotnego. Dlatego też konsumenci, dokonując zakupu, oczekują, że oferowane produkty będą spełniać najwyższe standardy bezpieczeństwa i jakości. Unia Europejska, w ramach jednolitego rynku, w interesie zdrowia publicznego wprowadza surowe procedury gwarantujące wysoki poziom bezpieczeństwa konsumentów. Unijna polityka skupia się na ochronie zdrowia w całym łańcuchu produkcji żywności [Kowalczyk 2016].

Produktem bezpiecznym określa się produkt, który w naturalnych do zastosowania warunkach oraz w sytuacjach związanych z oddaniem go do użytku, instalacją i/lub konserwacją nie stwarza żadnego zagrożenia albo jedynie nieznaczne zagrożenie uznane za dopuszczalne. W każdym innym wypadku wyrób uznaje się za niebezpieczny [Dyrektywa 2001/95/WE]. Rozporządzenie (WE) nr 178/2002 Parlamentu Europejskiego i Rady z dnia 28 stycznia 2002 r. określa zagrożenie jako czynnik fizyczny, chemiczny bądź biologiczny występujący w żywności lub stan żywności, który może wywołać szkodliwy wpływ na zdrowie i/lub życie ludzkie [Rozporządzenie (WE) nr 178/2002]. Do zanieczyszczenia żywności może dojść w trakcie całego łańcucha żywnościowego, tj. w trakcie przetwarzania, pakowania, transportu oraz magazynowania.

Za zagrożenie fizyczne uznaje się obecność i/lub występowanie w żywności substancji obcych i materiałów, które zwyczajnie nie znajdują się w żywności, a mogą spowodować fizyczne uszkodzenie ciała ludzkiego, np. jamy ustnej. Definiowane jest jako wolna substancja, której obecność nie jest oczekiwana przez konsumentów ani przez organy zajmujące się kontrolą przetwarzania i dystrybucji żywności. Źródeł tych zagrożeń jest wiele, mogą one pochodzić z surowców lub zanieczyszczeń żywności podczas procesów przetwarzania i dystrybucji. Przedsiębiorstwa produkcyjne, 
w celu ograniczenia powstawania zagrożeń fizycznych, są zobowiązane przeprowadzać odpowiednie kontrole oraz szkolenia pracowników [Zadernowski i in. 2008].

Zagrożeniem chemicznym są wszystkie związki chemiczne, które po spożyciu mogą wywołać u człowieka stany zatrucia chemicznego. Głównym źródłem tego zagrożenia są surowce, materiały pomocnicze, opakowania, maszyny i urządzenia. Do zagrożeń chemicznych pochodzenia technologicznego zalicza się różnego rodzaju środki czystości, oleje, farby, a także preparaty używane do dezynsekcji i deratyzacji. Wyróżnia się też środowiskowe zagrożenia chemiczne, które zostały wprowadzone do łańcucha żywnościowego podczas upraw rolnych lub w trakcie produkcji pasz. Są to m.in. pozostałości pestycydów, antybiotyków i leków weterynaryjnych oraz metale ciężkie [Dyjak i in. 2017].

Produkty żywnościowe mogą także być zanieczyszczone różnego rodzaju komórkami bakterii, wirusów, pleśni i grzybów, ponieważ są sprzyjającym środowiskiem do ich rozwoju. Niektóre rodzaje drobnoustrojów są bardzo pożądane, np. podczas przetwarzania fermentowanej żywności, czyli m.in. podczas produkcji serów dojrzewających, kefirów, alkoholi. Jednak obecność większości z nich może prowadzić do rozkładu żywności lub wywołać zatrucie pokarmowe u konsumentów. Źródłem drobnoustrojów w pożywieniu są głównie surowce pochodzenia roślinnego i zwierzęcego. Innymi źródłami mikroorganizmów w żywności są: powietrze, gleba, ścieki, urządzenia stosowane do produkcji żywności lub opakowania [Kołożyn-Krajewska, Sikora 2010]. Zagrożenie mikrobiologiczne to nieakceptowalne zanieczyszczenie, wzrost lub przeżywalność w żywności drobnoustrojów, które mogłyby spowodować jej rozkład gnilny lub wytwarzanie i utrzymywanie się w niej: toksyn bakteryjnych, enzymów, amin biogennych lub produktów ich metabolizmu. Podstawowym źródłem takich zagrożeń jest sam człowiek i nieprzestrzeganie przez niego zasad higieny żywności $\mathrm{w}$ procesie produkcyjnym. Zagrożenia mikrobiologiczne mogą również występować na skutek obecności szkodników w łańcuchu żywnościowym lub też pochodzić od surowców wykorzystywanych do produkcji [Wróbel 2014].

\section{Europejski system wczesnego reagowania - RASFF}

System RASFF (Rapid Alert System for Food and Feed) to europejski System Wczesnego Ostrzegania o Niebezpiecznej Żywności i Paszach. System ten jest zintegrowanym narzędziem umożliwiającym szybką wymianę informacji między krajami członkowskimi, dotyczących zagrożeń wykrytych w żywności, paszach oraz materiałach stosowanych do kontaktu z żywnością [Adamczyk 2014]. Członkowie sieci mogą szybko, skutecznie i bez opóźnień eliminować powstałe zagrożenia, zanim one zaszkodzą konsumentom. System ten jest ważnym elementem polityki ochrony zdrowia konsumentów w Unii Europejskiej. Skupia on swoje działania na minimalizacji powstałego ryzyka dzięki wykorzystaniu zintegrowanego systemu informatycznego. Natychmiastowa reakcja RASFF na pojawiające się zagrożenia żywności 
zapewnia bezpieczeństwo, pogłębia zaufanie konsumentów oraz gwarantuje wysoki poziom ochrony ich zdrowia. Dzięki efektywnej wymianie informacji o niebezpieczeństwach związanych z żywnością i paszą system RASFF gwarantuje, że niebezpieczna żywność będzie szybko eliminowana ze wspólnego rynku europejskiego [Michalska-Pożoga 2013; Stankiewicz 2012].

Członkami systemu RASFF są [Rozporządzenie (WE) nr 178/2002]:

1) Komisja Europejska (KE) odpowiedzialna za kierowanie systemem. Każdy członek sieci jest zobowiązany natychmiast (w ciągu 48 godzin od otrzymania informacji o zagrożeniu) powiadomić KE, jeśli posiada informacje o niebezpieczeństwach mogących zagrozić zdrowiu lub życiu człowieka, pochodzących od żywności lub pasz. Po otrzymaniu komunikatu Komisja Europejska natychmiast przekazuje informację innym członkom sieci. Jeśli ładunek, kontener lub partia zostaną odrzucone przez dany organ graniczny na terenie Unii Europejskiej, Komisja wysyła zawiadomienie do wszystkich posterunków granicznych zarówno europejskich, jak i państw trzecich.

2) Europejski Urząd do spraw Bezpieczeństwa Żywności (EFSA) zapewnia pomoc naukowo-techniczną i informacje odnoszące się do wszystkich dziedzin mających bezpośredni lub pośredni wpływ na zdrowie konsumentów takich jak bezpieczeństwo żywności i pasz, odżywianie, zdrowie i ochrona roślin. EFSA jest instytucją niezależną od Parlamentu i Komisji Europejskiej oraz państw członkowskich. Podstawową działalnością Urzędu jest przeprowadzanie naukowej oceny ryzyka. EFSA gromadzi i analizuje dane ułatwiające opracowanie charakterystyk i śledzenie zagrożeń wpływających na bezpieczeństwo żywności i pasz. Takie działania przyczyniają się do zachowania wysokiego poziomu ochrony życia i zdrowia ludzi oraz zwierząt [Kowalczyk 2016].

EFSA bezpośrednio współpracuje z organami zarządzającymi ryzykiem (Komisją Europejską, Parlamentem Europejskim, państwami członkowskimi UE) w zakresie badań naukowych, zbierania danych, kontroli i informacji. Profesjonalny personel naukowy odpowiada za przeprowadzanie ocen w ww. obszarach. Urząd organizuje ponadto spotkania $\mathrm{z}$ instytucjami reprezentującymi konsumentów i z przedstawicielami przemysłu w celu rozszerzania wiedzy o działaniach przez niego podejmowanych. EFSA prowadzony jest przez samodzielny zarząd, którego członkowie działają $\mathrm{w}$ interesie publicznym [Lendzion i in. 2010].

3) 28 państw czlonkowskich Unii Europejskiej oraz Norwegia, Liechtenstein, Szwajcaria i Islandia, których zadaniem w ramach systemu RASFF jest bezzwłoczne informowanie Komisji Europejskiej o:

- wykryciu wszelkich zagrożeń związanych z żywnością i paszami,

- wszystkich przyjętych rozwiązaniach ograniczających wprowadzenie na rynek żywności lub pasz,

- wycofaniu z rynku żywności lub pasz,

- każdym odrzuceniu partii, kontenera lub ładunku żywności, które zagrażały w bezpośredni lub pośredni sposób zdrowiu konsumentów [Kowalczyk 2016]. 
Uczestnictwo w systemie RASFF jest otwarte dla państw trzecich, krajów kandydujących oraz różnych międzynarodowych organizacji w oparciu o umowy zawarte między nimi a Unią Europejską. Polska została przyłączona do sieci systemu w maju $2004 \mathrm{r}$.

\section{Sposób funkcjonowania systemu RASFF}

Podstawą prawną działania systemu RASFF jest Rozporządzenie (WE) nr 178/2002 Parlamentu Europejskiego i Rady z dnia 28 stycznia 2002 r., które wyznacza uniwersalne zasady i wymagania prawa żywnościowego. System ten jest zbudowany na zasadzie zintegrowanej sieci [Rozporządzenie (WE) nr 178/2002]. Kraje członkowskie należące do systemu posiadają na terenie swojego państwa krajowy punkt kontaktowy (KPK), którego zadaniem jest reprezentowanie danego kraju. Wszystkie KPK mają obowiązek zapewnić dyżurującego urzędnika przez 7 dni w tygodniu i 24 godziny na dobę. Punkty te mają własne adresy e-mail, na które przesyłane są informacje rozpowszechniane w systemie. Do wymiany informacji w sieci RASFF służą odpowiednio sporządzone formularze. KPK jest odpowiedzialny za gromadzenie informacji o bezpośrednich lub pośrednich zagrożeniach pochodzących z żywności lub pasz. Następnie informacja jest przekazywana do Komisji Europejskiej, której zadaniem są weryfikacja i natychmiastowe zawiadomienie pozostałych członków systemu. Członkowie systemu otrzymują informacje o tym, w jakim produkcie wykryto zagrożenie oraz jakie wszczęto działania w celu eliminacji ryzyka. Otrzymane informacje pozwalają krajom członkowskim na bieżąco kontrolować, czy dane zagrożenie ich dotyczy [Komisja Europejska 2017].

Komisja, zanim prześle otrzymane powiadomienia do wszystkich członków sieci, ma obowiązek je zweryfikować. Sprawdza pełność i przejrzystość powiadomienia oraz dobór odpowiednich słowników danych. Weryfikuje zgodność powiadomienia z wymogami zawartymi w Rozporządzeniu Parlamentu i Rady (WE) nr 178/2002 oraz Rozporządzeniu Komisji (UE) nr 16/2011[Rozporządzenie (WE) nr 178/2002; Rozporządzenie Komisji (UE) nr 16/2011]. Komisja ma również za zadanie zapewnić, by informacje były przekazywane w prostym języku, łatwo zrozumiałym dla członków sieci. Po weryfikacji alertów Komisja Europejska przygotowuje dokument, który zawiera kod identyfikacyjny, stronę główną uwzględniającą typ powiadomienia i rodzaj zagrożenia, treść zawiadomienia w oryginalnej wersji językowej wraz z przetłumaczeniem na język angielski, załączone dokumenty (raporty z badań, certyfikaty).

Jeżeli istnieje przypuszczenie, że dana żywność lub pasza pochodzące z rynków europejskich lub państw trzecich mogą zagrozić zdrowiu ludzi i zwierząt albo wpłynąć negatywnie na środowisko naturalne, to Komisja podejmuje następujące środki, takie jak:

a) wstrzymanie wprowadzania na rynek lub spożywania danej żywności lub paszy, 
b) wyznaczenie szczególnych warunków dla danej żywności lub paszy,

c) stosowanie innych tymczasowych środków ochrony [Komisja Europejska 2017].

Powiadomienia przesyłane przez krajowe punkty kontaktowe do punktu kontaktowego Komisji Europejskiej są składane z zastosowaniem specjalnie przygotowanych formularzy. Powiadomienia te dzieli się na pierwotne (alarmowe, informacyjne, o odrzuceniu na granicy) i uzupełniające [Krzepkowska 2015; Rozporządzenie Komisji (UE) nr 16/2011], tj.:

a) powiadomienia alarmowe przesyłane są wówczas, gdy zagrożenie wymaga podjęcia natychmiastowych działań (np. wycofanie produktu) w państwie będącym członkiem sieci. Zwykle dotyczą sytuacji, gdy zidentyfikowana żywność lub pasza stwarzają istotne zagrożenie dla zdrowia oraz życia konsumentów. Krajowe punkty kontaktowe mają obowiązek powiadomić w ciągu 48 godzin punkt kontaktowy Komisji Europejskiej od chwili odebrania informacji o zagrożeniu bezpieczeństwa żywności lub paszy. Powiadomienie takie powinno zawierać wszelkie dostępne informacje obejmujące rodzaj zagrożenia i rodzaj produktu, którego dotyczy zagrożenie. Następnie informacje te są weryfikowane przez Komisję i przesyłane członkom sieci nie później niż po 24 godzinach od ich otrzymania;

b) powiadomienia informacyjne przesyłane są, gdy zidentyfikowano ryzyko, jednak członkowie nie muszą podejmować natychmiastowych działań, ponieważ dany produkt nie jest już obecny na ich rynku lub znajduje się wyłącznie na rynku państwa, które wysyła powiadomienie. Taki produkt nie stwarza bezpośredniego niebezpieczeństwa, ale istnieje prawdopodobieństwo ponownego wprowadzenia go na rynek. W tym wypadku organy RASFF powinny podjąć działania zapobiegające takiej sytuacji;

c) powiadomienie o odrzuceniu na granicy - jest to powiadomienie oznaczające odrzucenie partii, kontenera, ładunku żywności lub paszy w związku z podejrzeniem zagrożenia dla zdrowia ludzi oraz zwierząt. Punkt kontaktowy Komisji przesyła to powiadomienie do punktów kontroli granicznej;

d) powiadomienia NEWS to zgłoszenia mające związek z bezpieczeństwem żywności i pasz, które zostały przyjęte przez urzędy kontroli jako powiadomienia godne uwagi. Powiadomienia te są często oparte na informacjach pochodzących z mediów lub organizacji międzynarodowych;

e) powiadomienia uzupelniające to wszelkie dodatkowe informacje związane $\mathrm{z}$ danym produktem lub zagrożeniem, które zostały zgłoszone w powiadomieniu pierwotnym.

Graficzne znaki stosowane do oznaczania powiadomień wysyłanych przez RASFF przedstawiono na rys. 1.

Schemat funkcjonowania systemu RASFF przedstawiono na rys. 2.

Od początku funkcjonowania systemu wszelkie przesyłane powiadomienia są archiwizowane. Natomiast od maja 2003 r. Komisja Europejska upowszechnia raporty obejmujące powiadomienia odebrane w określonym czasie. Raporty te są do- 

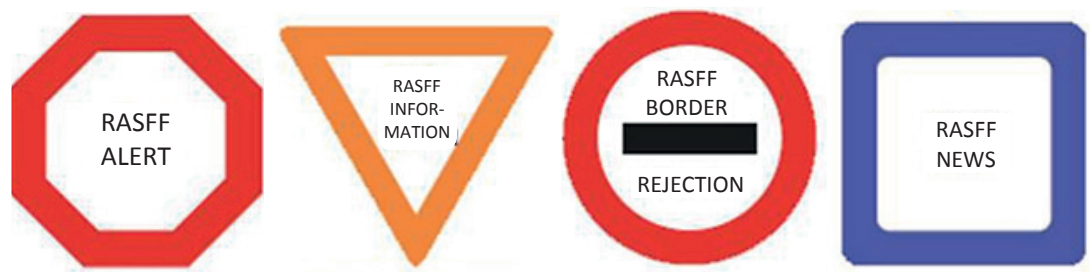

Rys. 1. Rodzaje oznaczania powiadomień wysyłanych przez RASFF

Fig. 1. Types of notifications sent by RASFF

Źródło/Source: opracowanie własne na podstawie/own study on the basis of [http://www.primoris-lab. com/en/support/legislation/rasff-notifications/].

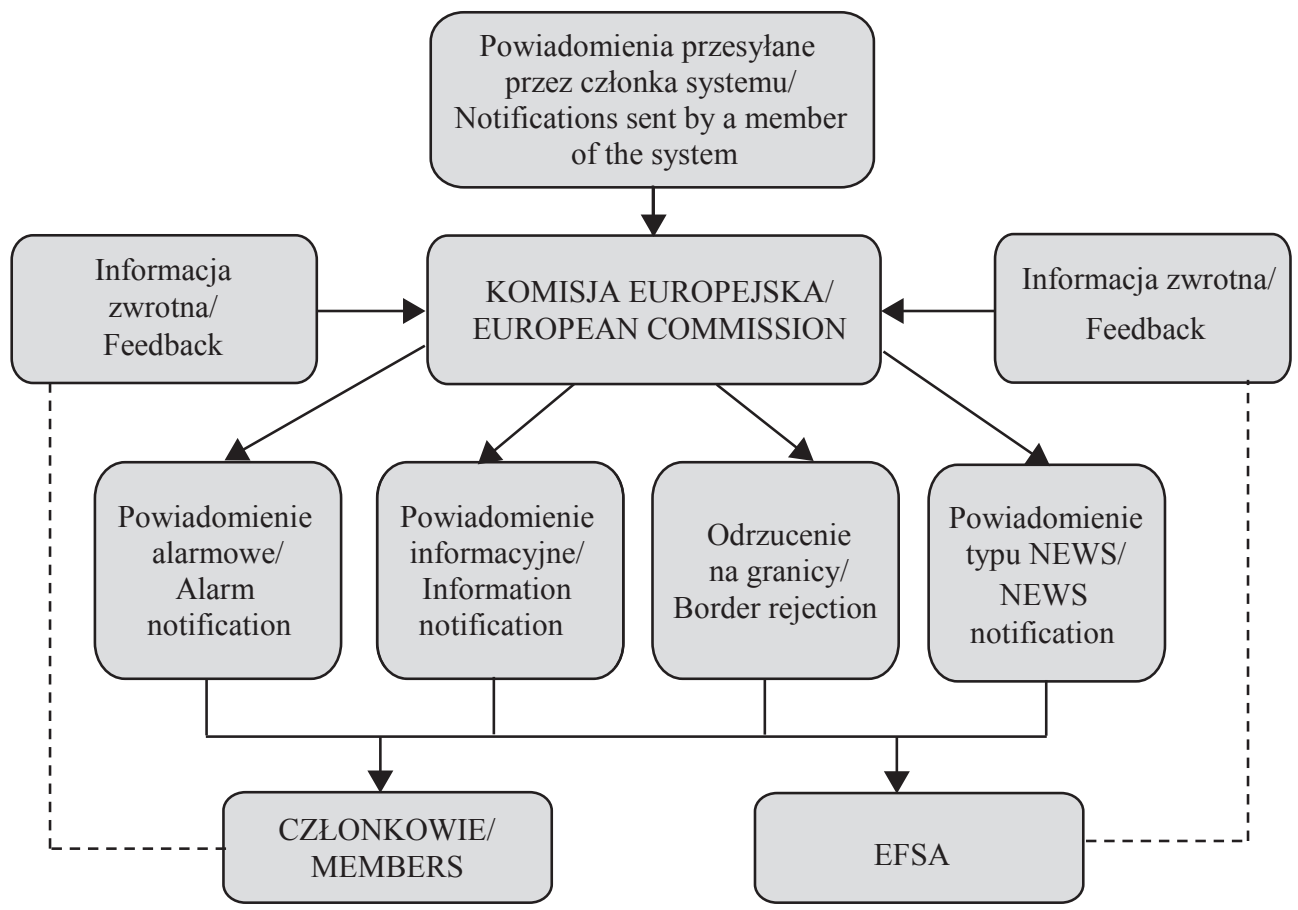

Rys. 2. Schemat działania systemu RASFF

Fig. 2. The scheme of the RASFF system

Źródło/Source: opracowanie własne na podstawie/ own study on the basis of [Michalska-Pożoga 2013].

stępne na oficjalnej stronie internetowej Komisji Europejskiej pod adresem https:// ec.europa.eu/food/safety/rasff_en. Dzięki temu społeczeństwo ma dostęp do informacji dotyczących identyfikacji produktu, kraju pochodzenia, rodzaju ryzyka i podjętych przeciwdziałań [Michalska-Pożoga 2013].

W Polsce systemem RASFF zarządza Główny Inspektor Sanitarny, który ustanawia krajowe punkty kontaktowe (KPK) oraz jest odpowiedzialny za wysyłanie po- 
wiadomień do Komisji Europejskiej o odnotowanej na terenie kraju nieprawidłowości wykrytej w żywności bądź w paszach. W Polsce nadzór nad bezpieczeństwem żywności przebiega na dwóch płaszczyznach. Wyróżnia się wewnętrzną i zewnętrzną kontrolę żywności. Kontrola wewnętrzna obejmuje przepisy i systemy jakości wprowadzone przez producenta w celu zachowania bezpieczeństwa zdrowotnego produktów. Natomiast kontrola zewnętrzna przeprowadzana jest przez państwowe inspekcje, których zadaniem jest nadzorowanie produkowanej żywności. Producenci oraz powiatowe, graniczne i wojewódzkie instytucje urzędowej kontroli żywności gromadzą informacje o wyrobach, które mogą być niebezpieczne i przesyłają je do KPK. Następnie eksperci z punktów kontrolnych oceniają możliwe ryzyko związane z produktem i ustalają plan dalszego postępowania [Kononiuk 2018].

\section{Analiza powiadomień przesylanych za pomocą systemu RASFF}

Niniejszy punkt poświęcony jest analizie liczby powiadomień przesyłanych za pomocą Systemu Wczesnego Ostrzegania o Niebezpiecznej Żywności i Paszach ze względu na różne czynniki. Wszelkie dane potrzebne do sporządzenia wykresów

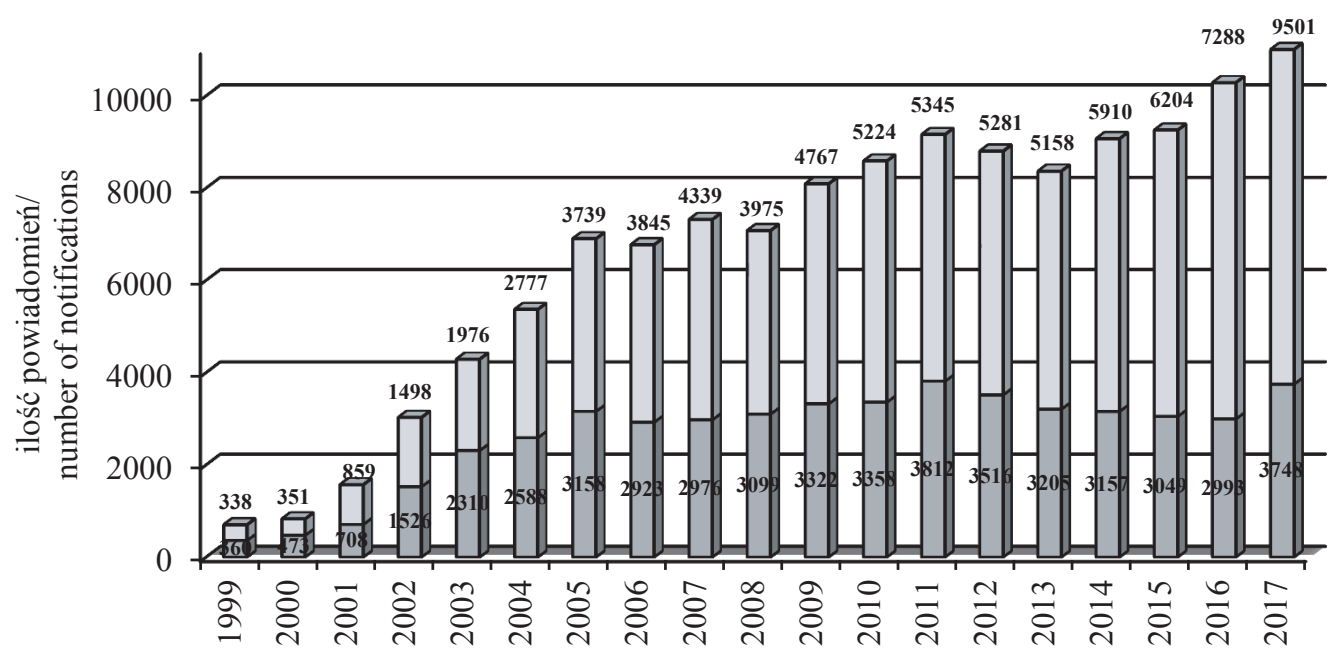

$\square$ powiadomienia uzupełniające/follow-up notifications $\square$ powiadomienia pierwotne/original notifications

Rys 3. Liczba powiadomień zgłoszonych do RASFF w poszczególnych latach

Fig. 3. The number of notifications received for RASFF in different years

Źródło/Source: opracowanie własne na podstawie/own study on the basis of [https://ec.europa.eu/food/ safety/rasff/reports_publications_en; https://ec.europa.eu/food/sites/food/files/safety/docs/rasff_ annual_report_2017.pdf; https://ec.europa.eu/food/sites/food/files/safety/docs/rasff_annual_report_2011_en.pdf; https://webgate.ec.europa.eu/rasff-window/portal/?event=searchForm; https:// ec.europa.eu/food/sites/food/files/safety/docs/rasff_annual_report_2006_en.pdf; https://ec.europa. $\mathrm{eu} / \mathrm{food} / \mathrm{sites} / \mathrm{food} / \mathrm{files} / \mathrm{safety} /$ docs/rasff_annual_report_2002_en.pdf]. 
zostały uzyskane z przygotowanej przez Komisję Europejską wyszukiwarki, która znajduje się pod adresem: https://webgate.ec.europa.eu/rasff-window/portal.

Na rys. 3 przedstawiono, jak w latach 1999-2017 zmieniała się liczba powiadomień zgłaszanych za pomocą systemu RASFF. W latach 1999-2005 można zaobserwować tendencję wzrostową alertów. Natomiast w 2006 r. odnotowano pierwszy spadek powiadomień w porównaniu z rokiem ubiegłym o 129 notyfikacji. W następnych latach liczba powiadomień wzrastała, jednak w niektórych latach odnotowano przejściowe spadki. W 2016 r. liczba ta przekroczyła wartość 10 000. Liczba przesyłanych alertów w analizowanym okresie wykazała tendencję wzrostową, co nie musi świadczyć o zwiększaniu się zagrożenia konsumentów. Trend wzrostowy może wynikać z coraz większej świadomości i chęci poszczególnych państw do dbania o zdrowie konsumentów na wspólnym rynku.

Od momentu przyłączenia Polski do systemu RASFF (maj 2004 r.) do połowy 2018 r. całkowita liczba powiadomien pierwotnych przesyłanych w ramach tego systemu wyniosła 44969 [https://webgate.ec.europa.eu/rasff-window/portal/?even$\mathrm{t}=$ searchResultList], przy czym 39770 alertów dotyczyło żywności, co stanowiło $88 \%$ wszystkich powiadomień (rys. 4). W odniesieniu do paszy dla zwierząt odnotowano 3075 alertów (7\%). Natomiast 2124 powiadomień dotyczyło materiałów przeznaczonych do kontaktu z żywnością, co stanowiło 5\% łącznej liczby notyfikacji.

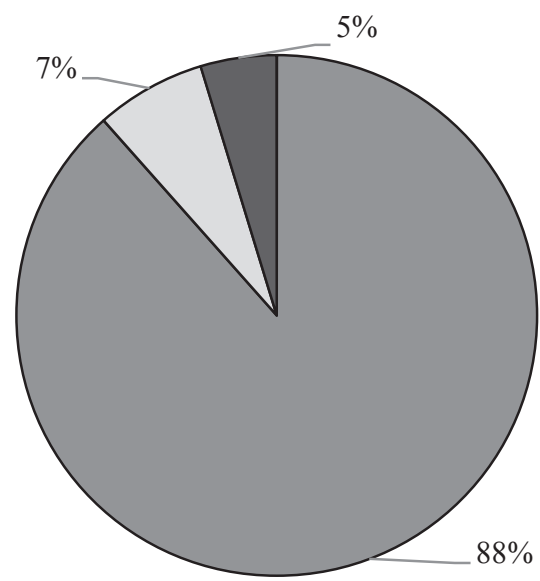

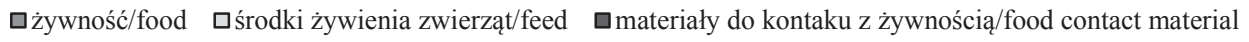

Rys. 4. Podział powiadomień przesyłanych w latach 2004-2018 ze względu na typ produktu

Fig. 4. Distribution of notifications sent in 2004-2018 in terms of the type of products

Źródło/Source: opracowanie własne na podstawie/own study on the basis of [https://webgate.ec.europa.eu/rasff-window/portal/?event=searchForm]. 
W latach 2004-2018 Włochy przesłały najwięcej, bo aż 7352 powiadomień i są wyraźnym liderem w tej dziedzinie. Największy odsetek alertów dotyczył ryb i produktów rybnych (1829), które najczęściej były zanieczyszczone metalami ciężkimi (750). W analizowanym okresie na drugim miejscu znalazły się Niemcy z liczbą powiadomień 5501, a tuż za nimi Wielka Brytania (5067). Niemcy wśród przekazywanych powiadomień najczęściej informowali o orzechach i nasionach zanieczyszczonych mikotoksynami (1511). Natomiast Wielka Brytania w większości zgłaszała owoce i warzywa (1092), w których zidentyfikowano pozostałości pestycydów lub mikroorganizmów chorobotwórczych. Polska zajęła 8 miejsce pod względem liczby przesyłanych powiadomień - 1694. W tym okresie wprowadziła do systemu 1694 powiadomień pierwotnych - 1386 związanych z żywnością, 155 dotyczących materiałów do kontaktu z żywnością i 147 pasz dla zwierząt - co stanowiło 3,77\% ogólnej liczby tych powiadomień. Statystyki podobnie wskazują, że najpoważniejsze źródło zagrożeń stanowiła żywność.

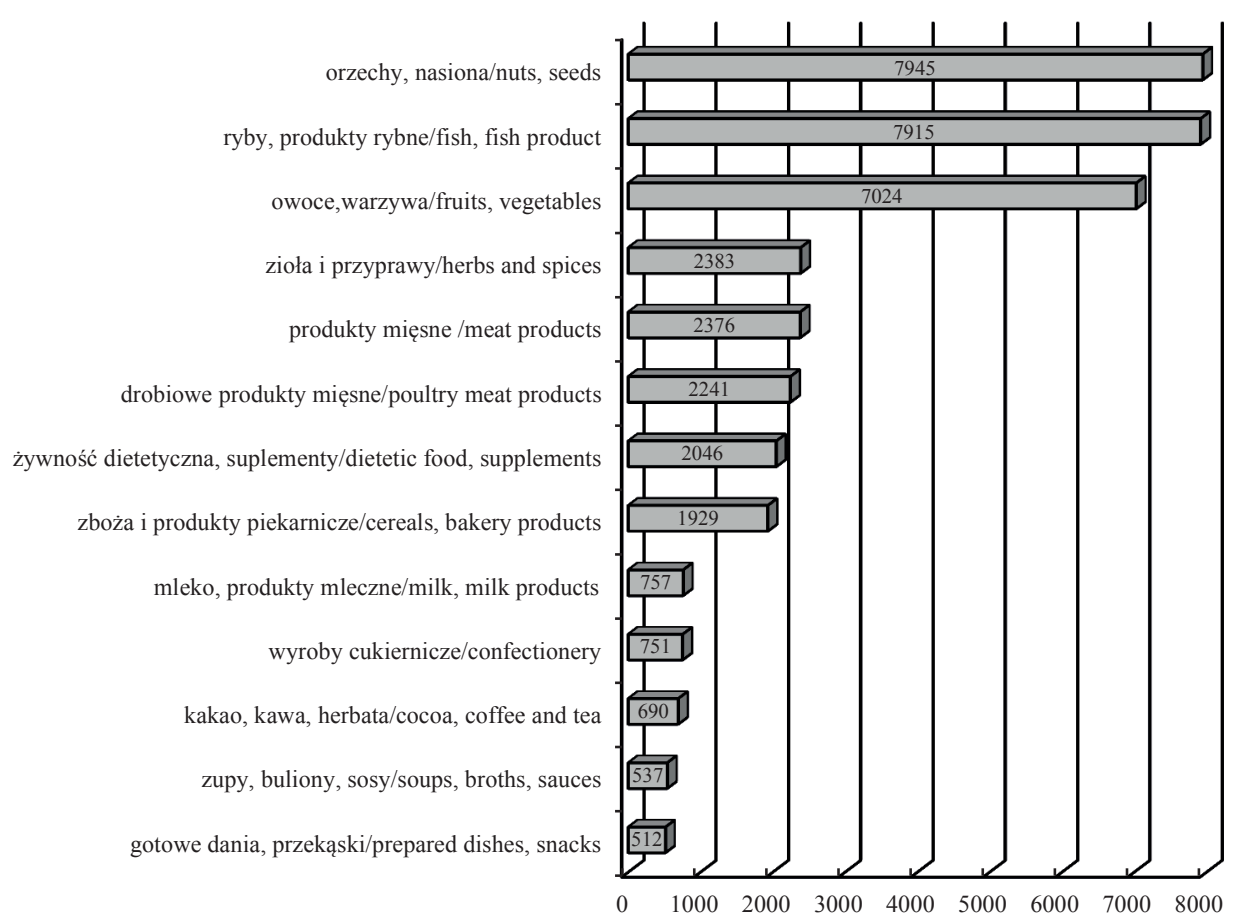

liczba powiadomien/the number of notifications

Rys. 5. Powiadomienia dotyczące żywności według kategorii produktu w latach 2004-2018

Fig. 5. Food notifications by product category in 2004-2018

Źródło/Source: opracowanie własne na podstawie/own study on the basis of [https://webgate.ec. europa.eu/rasff-window/portal/?event=searchForm]. 
Na rys. 5 przedstawiono wybrane kategorie produktów żywnościowych i liczbę alertów przesyłanych do systemu RASFF. Największą liczbę zgłaszanych produktów żywnościowych do systemu stanowiły orzechy i nasiona - 7945. Głównym źródłem zagrożenia tej grupy produktów są pleśnie zwane aflatoksynami, które stanowią ponad $80 \%$ powiadomień w tej kategorii wyrobów. Mogą one powodować poważne dolegliwości ludzkiego układu pokarmowego. Najczęstszą przyczyną powstawania pleśni jest przechowywanie i transportowanie żywności w nieodpowiednich warunkach (np. duża wilgotność) [Lagana i in. 2017]. Drugą z kolei grupą o najwyższej liczbie notyfikacji były ryby i owoce morza - 7915, które często narażone są na zanieczyszczenia metalami ciężkimi, co może wynikać ze skażenia wód ściekami, ropą naftową, odpadami pochodzącymi z przemysłu itp. Kolejną grupą wyrobów najczęściej zgłaszanych do RASFF z liczbą 7024 powiadomień są owoce i warzywa. Te z kolei w 43\% zanieczyszczone były pozostałościami pestycydów. Pestycydy są używane w walce ze szkodnikami, jednak w wypadku nieprawidłowego ich stosowania, jak np. zbyt duża dawka, mogą one pozostać w żywności i stanowić niebezpieczeństwo dla konsumenta [Dyjak i in. 2017]. Zioła i przyprawy,

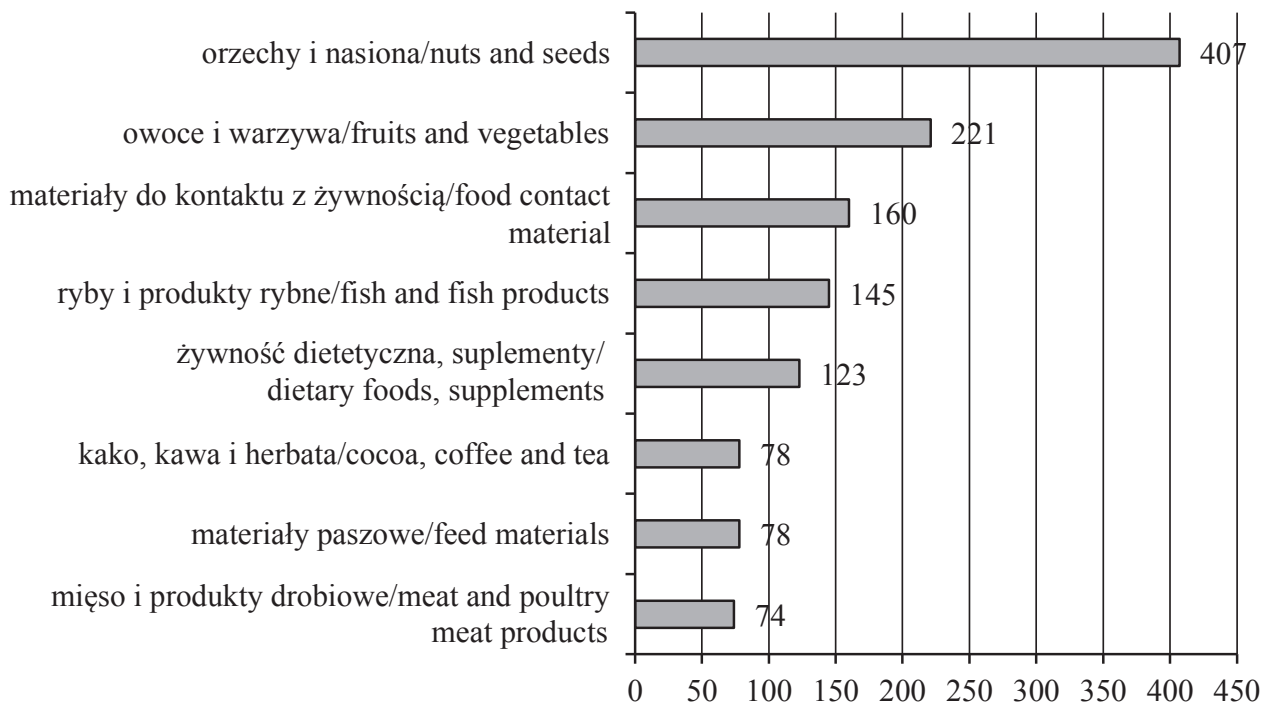

liczba powiadomien/the number of notifications

Rys. 6. Produkty zgłaszane przez Polskę za pośrednictwem RASFF w latach 2004-2018

Fig. 6. Products submitted by Poland to the RASFF system in the years 2004-2018

Źródło/Source: opracowanie własne na podstawie/own study on the basis of [https://webgate.ec.europa.eu/rasff-window/portal/?event=searchForm]. 
mięso oraz żywność dietetyczna i suplementy diety są to grupy produktów, na które również należy zwrócić szczególną uwagę w kwestii bezpieczeństwa żywności, gdyż w analizowanym okresie liczba powiadomień do systemu przekroczyła 2000.

Z kolei na rys. 6 przedstawiono najczęściej zgłaszane produkty przez państwo Polskie w latach 2004-2018 do systemu RASFF. Można zauważyć, że państwo Polskie w analizowanym okresie zgłosiło do systemu 407 alertów dotyczących orzechów i nasion. Produkty te w znacznym stopniu były zanieczyszczone ciałami obcymi (192 powiadomienia) lub mikotoksynami (120 powiadomień). Na drugim miejscu, z liczbą 221 powiadomień, znalazły się warzywa i owoce. Więcej niż 100 powiadomień przekazywanych przez Polskę dotyczyło materiałów przeznaczonych do kontaktu z żywnością, ryb oraz żywności wzbogaconej i dietetycznej.

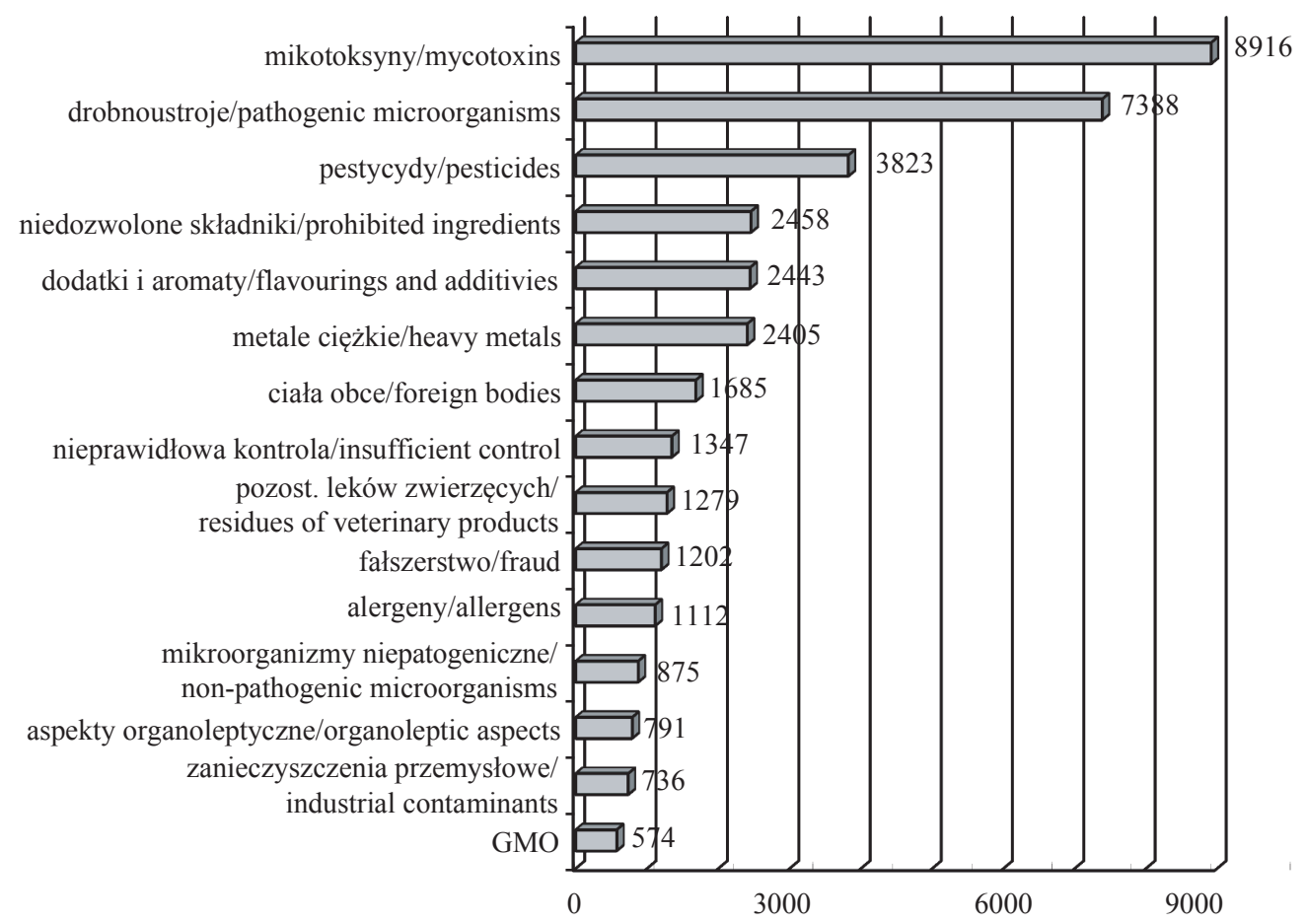

liczba powiadomien the number of notifications

Rys. 7. Najczęściej występujące zagrożenia żywności zgłaszane do systemu RASFF w latach 2004-2018 Fig. 7. The most frequent food hazards reported to the RASFF system in 2004-2018

Źródło/Source: opracowanie własne na podstawie/own study on the basis of [https://webgate.ec.europa.eu/rasff-window/portal/?event=searchForm]. 
Na rys. 7 zestawiono najczęściej pojawiające się zagrożenia żywności zgłaszane do systemu RASFF. Można zaobserwować, że największą liczbę zagrożeń stanowią mikotoksyny - 8916. Jak już wcześniej wspomniano, ich zdecydowana większość występuje w orzechach i nasionach (6414), jednak odnotowano również 1193 alerty w owocach i warzywach i 742 alerty w ziołach i przyprawach. Mikotoksyny stanowią poważną grupę zagrożeń, dlatego też władze Unii Europejskiej zaostrzyły warunki kontroli poszczególnych wyrobów importowanych m.in. z Chin, Iranu, Turcji, Egiptu, Argentyny, Brazylii. W zależności od wyników kontroli dalsze rozporządzenia będą odpowiednio uzupełniane i modyfikowane [Ledzion i in. 2010]. Kolejną grupę zagrożeń żywności odnotowanych 7388 razy stanowią drobnoustroje chorobotwórcze. Najczęściej występującymi drobnoustrojami chorobotwórczymi są bakterie z grupy Salmonella, które występują w mięsie, rybach, owocach morza, jajach i innych produktach pochodzenia zwierzęcego.

Źródłem wcześniej wymienionych zagrożeń żywności mogą być niska trwałość produktu, nieprawidłowy transport i magazynowanie, niewystarczające środki kontroli podczas produkcji i/lub sposób prowadzenia uprawy. Dlatego też ważnym

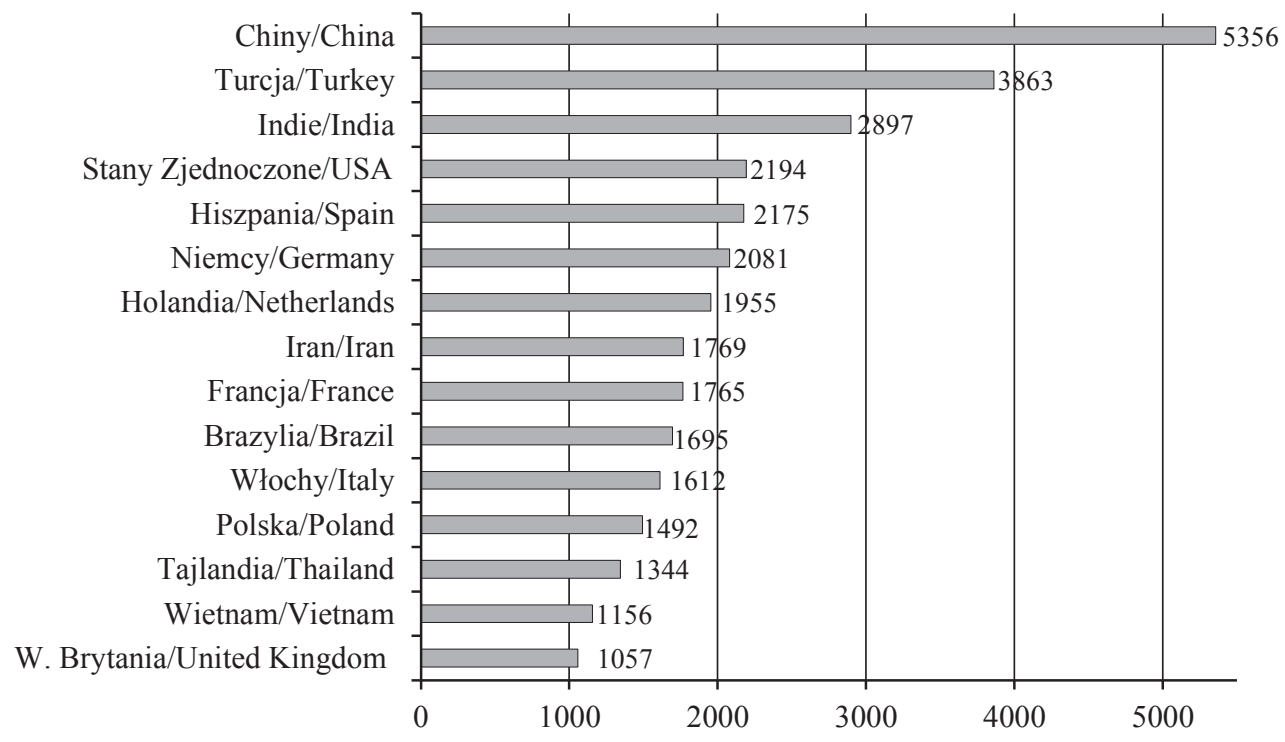

Rys. 8. Liczba powiadomień w systemie RASFF w latach 2004-2018 ze względu na pochodzenie produktu

Fig. 8. The number of notifications in the RASFF system in 2004-2018 in terms of the origin of the product

Źródło/Source: opracowanie własne na podstawie/ own study on the basis of [https://webgate.ec.europa.eu/rasff-window/portal/?event=searchForm]. 
aspektem jest monitorowanie przebiegu procesów w całym łańcuchu produkcji [Kowalczyk 2016].

Na rys. 8 przedstawiono liczbę alertów ze względu na miejsce pochodzenia zagrożonego produktu w okresie od maja 2004 do czerwca 2018 r. Wynika z nich, że najczęściej zgłaszane wyroby, mogące stanowić zagrożenie dla klientów, pochodziły z państw trzecich. Zdecydowanie największa liczba zgłoszonych produktów pochodziła z Chin - 5356 powiadomień. Na drugim miejscu, z liczbą 3863 powiadomień, znalazła się Turcja, na trzecim Indie - 2897 powiadomień, a na czwartym Stany Zjednoczone - 2194 powiadomień. Na pierwszym miejscu w Europie, a zarazem piątym na świecie była Hiszpania - 2175 zgłoszonych produktów. Natomiast produkty pochodzące z Polski były zgłaszane przez państwa członkowskie 1492 razy. $\mathrm{Z}$ analizy przedstawionych danych wyraźnie wynika, że produkty zagrażające bez-

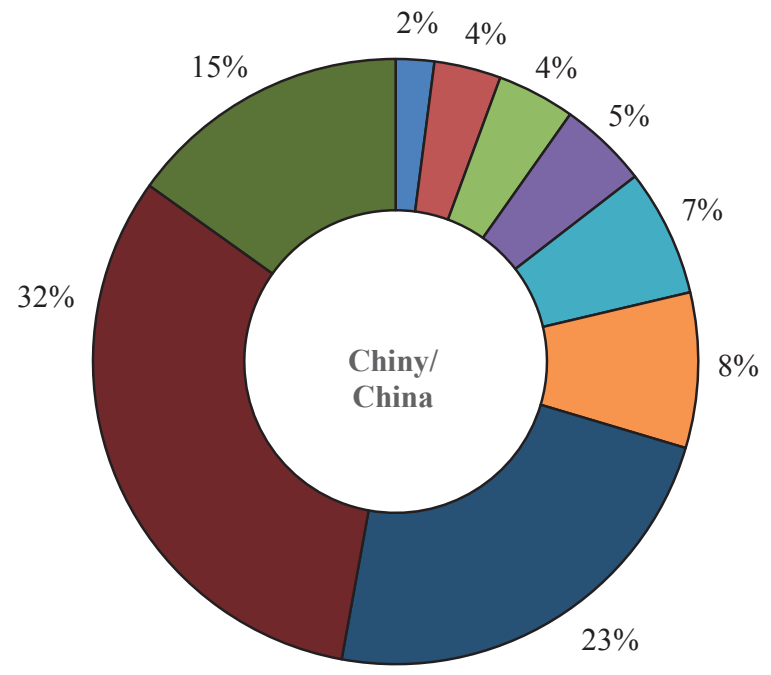

口zioła, przyprawy/herbs spices

口kakao, kawa, herbata/cocoa, coffee, tea

口ryby, produkty rybne/fish, fish products

口żywność dietetyczna, suplementy, żywność wzbogacona/dietetic food, supplements, fortified foods

口zboża, produkty piekarnicze/cereals, bakery products

$\square$ owoce, warzywa/fruits, vegetables

口orzechy, nasiona/nuts, seeds

- materiały do kontaktu z żywnością/food contact materials

口inne/other

Rys. 9. Rodzaje wyrobów pochodzących z Chin zgłoszonych do RASFF

Fig. 9. Types of products made in China submitted to RASFF system

Źródło/Source: opracowanie własne na podstawie/ own study on the basis of [https://webgate.ec.europa.eu/rasff-window/portal/?event=searchForm]. 
pieczeństwu konsumentów pochodziły z państw trzecich. Można więc wnioskować, że systemy bezpieczeństwa żywności w tych państwach nie funkcjonują tak sprawnie jak w państwach należących do Unii Europejskiej.

Charakterystyczne jest, że materiały przeznaczone do kontaktu z żywnością pochodzące z Chin stanowiły 32\% całkowitej liczby alertów (1715 powiadomień) pochodzących z tego kraju (rys. 9). Całkowita liczba powiadomień w analizowanym okresie związanych z wyrobami mającymi kontakt z żywnością wynosiła 2124 . Wynika $\mathrm{z}$ tego, że niemal $81 \%$ niebezpiecznych materiałów wyprodukowano w Chinach. Materiały te w większości wykazywały migrację niebezpiecznych cząsteczek do żywności (902 alerty) lub były zanieczyszczone metalami ciężkimi (767 aler-

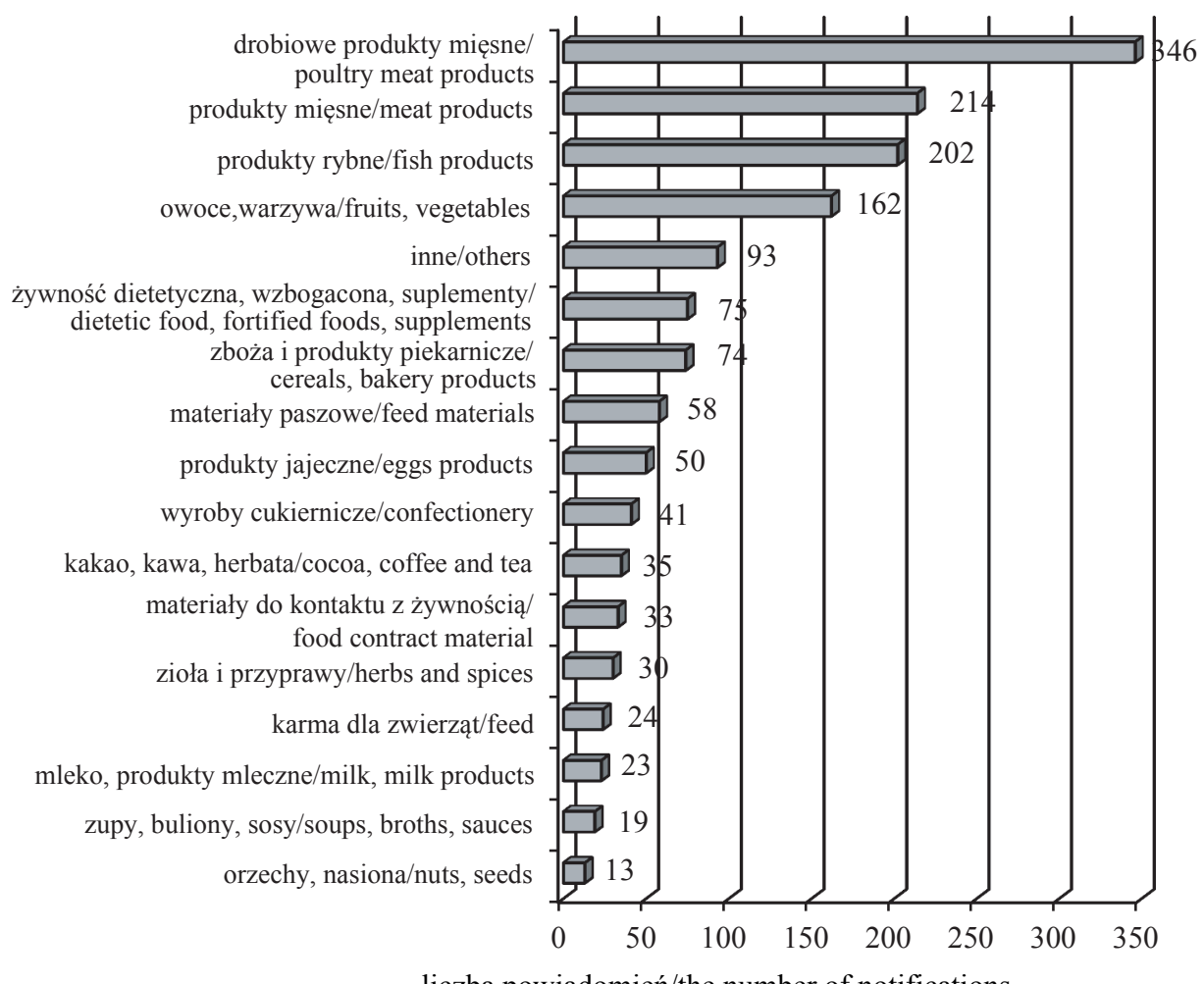

liczba powiadomien'/the number of notifications

Rys. 10. Liczba poszczególnych produktów pochodzących z Polski zgłoszonych do systemu RASFF w latach 2004-2018

Fig. 10. The number of individual products made in Poland submitted to the RASFF system in the years 2004-2018

Źródło/Source: opracowanie własne na podstawie/own study on the basis of [https://webgate.ec.europa.eu/rasff-window/portal/?event=searchForm]. 
tów). Kolejną grupą stanowiącą $23 \%$ powiadomień były orzechy, produkty orzechowe oraz nasiona (1245 powiadomień). Produkty te aż w $83 \%$ stwarzały niebezpieczeństwo z powodu zawartości mikotoksyn - 1031 powiadomień. Pozostałe grupy wyrobów otrzymały liczbę powiadomień nieprzekraczającą $8 \%$ w stosunku do całości. Ilość tych powiadomień wpływa na zwiększoną częstotliwość przeprowadzania przez Komisję Europejską urzędowych kontroli tych wyrobów.

Na kolejnym rys. 10 przedstawiono liczbę poszczególnych wyrobów zgłoszonych do systemu RASFF, które zostały wyprodukowane w Polsce. Od maja 2004 r. zgłoszono 1492 wyroby mogące zagrozić zdrowiu konsumentów państw członkowskich. Największą liczbę z tych produktów stanowiło mięso i produkty drobiowe 346, a także mięso inne niż drób - 214 alertów. Wysoką liczbę zanieczyszczonych produktów zgłoszonych do systemu stanowiły również ryby (202) oraz owoce i warzywa (162). Źródłem zagrożeń mięsa i ryb pochodzących z Polski były w szczególności drobnoustroje chorobotwórcze - w przypadku mięsa były to bakterie z grupy Salmonella enterica, natomiast w odniesieniu do ryb bakterie Listeria monocytogenes. Owocami najczęściej zgłaszanymi do systemu okazały się jabłka, a źródłem zagrożenia były pozostałości pestycydów. W Polsce najczęściej eksportowanymi owocami są właśnie jabłka, co z pewnością wpływa na wysoką liczbę notyfikacji [Kierczyńska 2015].

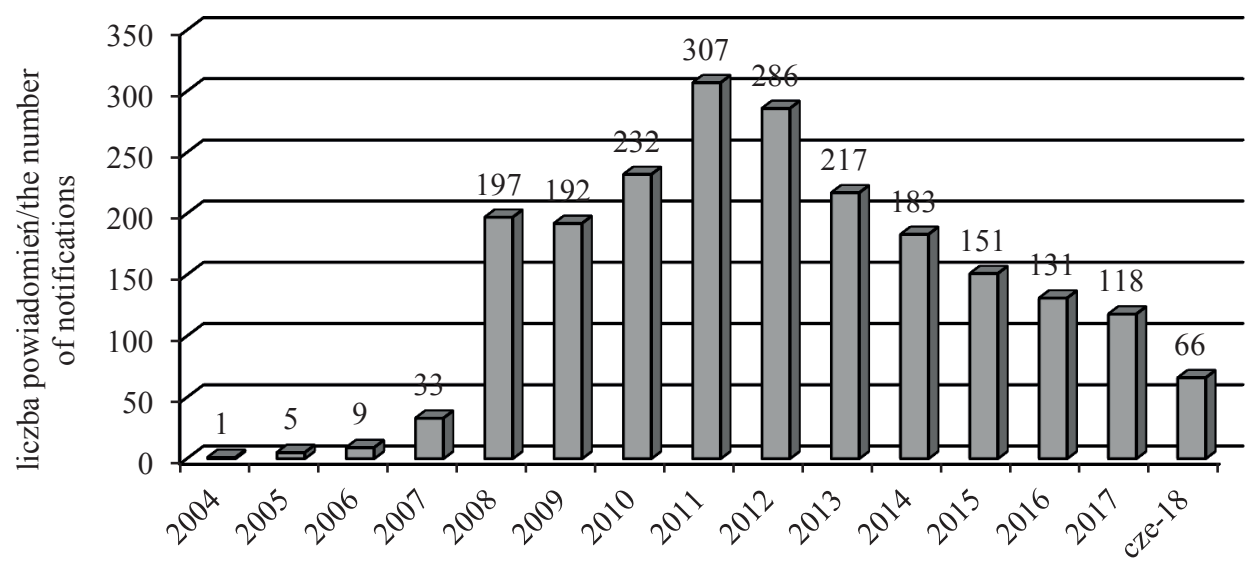

Rys. 11. Liczba powiadomień dotycząca materiałów przeznaczonych do kontaktu z żywnością w ramach systemu RASFF w latach 2004-2018

Fig. 11. Number of notifications regarding materials intended for contact with food under the RASFF system in 2004-2018

Źródło/Source: opracowanie własne na podstawie/ own study on the basis of [https://webgate.ec.europa.eu/rasff-window/portal/?event=searchForm]. 
W wypadku zagrożeń ze strony materiałów przeznaczonych do kontaktu z żywnością w latach 2004-2018 odnotowano 2124 powiadomień (rys. 11). Zaobserwowano tendencję wzrostową alertów w latach 2004-2011, co mogło być związane z innowacyjnością i ciągłym rozwojem tej gałęzi przemysłu żywnościowego.Pojawiające się nowoczesne materiały zwiększają liczbę możliwych zagrożeń związanych w szczególności z migracją szkodliwych cząstek do żywności. W kolejnych latach zaobserwowano trend spadkowy liczby powiadomień, co może świadczyć o coraz większej świadomości konsumentów co do zagrożeń skutkującej polepszaniem przez producentów jakości swoich wyrobów.

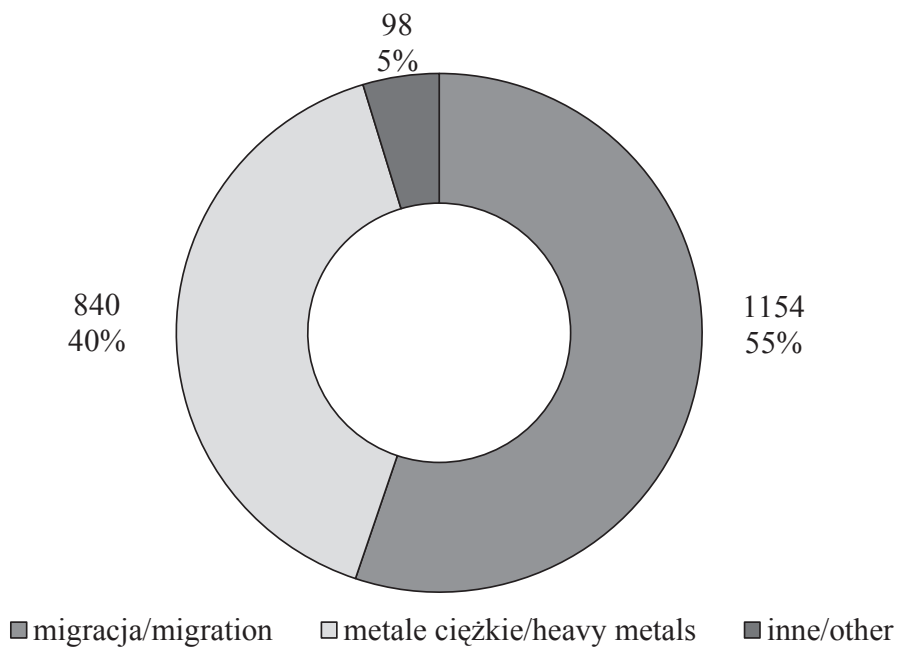

Rys. 12. Liczba zagrożeń zgłoszonych do systemu RASFF wykrytych w materiałach przeznaczonych do kontaktu z żywnością w latach 2004-2018

Fig. 12. Number of danger submitted to the RASFF system detected in materials intended for contact with food in 2004-2018

Źródło/Source: opracowanie własne na podstawie/own study on the basis of [https://webgate.ec.europa.eu/rasff-window/portal/?event=searchForm].

Najczęściej odnotowane zagrożenia zdrowia konsumenta wykryte w materiałach przeznaczonych do kontaktu z żywnością w latach 2004-2018 dotyczyły migracji substancji małocząsteczkowych do żywności (rys. 12). Są to nie w pełni przereagowane monomery oraz dodatki stosowane podczas procesu produkcyjnego tworzyw sztucznych. Natomiast gorszej jakości szklane lub ceramiczne wyroby mogą uwalniać metale ciężkie. Niektóre z nich są szkodliwe nawet w śladowych ilościach. 


\section{Falszowanie żywności}

W celu utrzymania wysokich norm bezpieczeństwa żywności ważnym aspektem działania Wspólnoty jest walka z nieuczciwymi praktykami w branży żywnościowej. Zakłada się, że do oszustwa dochodzi na skutek umyślnego naruszenia wspólnotowego prawa żywnościowego. Fałszowanie żywności obejmuje świadome działania wpływające na zmianę składu produktu składnikami mniej wartościowymi oraz informacje wprowadzające w błąd w celach ekonomicznych. Przyczyną takich działań jest zwiększenie zysków finansowych poprzez obniżenie kosztów produkcyjnych, ukrycie prawdziwego pochodzenia lub niskiej jakości wyrobów, a także uzyskanie większej przewagi konkurencyjnej. W wyniku takich działań konsument zostaje wprowadzony w błąd [Kowalska i in. 2018; Puchlik 2011].

Jedną z funkcji RASFF jest zapobieganie fałszowaniu żywności. Gdy produkty zgłoszone za pośrednictwem systemu RASFF są wynikiem fałszerstwa, zostaje uruchomiona specjalna unijna sieć, której działania skupiają się na przeciwdziałaniu zafałszowaniu żywności (FFN - UE Food Fraud Network). Sieć ta została uruchomiona w lipcu 2013 r. po wybuchu afery związanej z fałszowaniem mięsa wołowego koniną w Wielkiej Brytanii [Sawicki 2014]. Działania sieci FFN skupiają się na przypadkach zafałszowania żywności, które zostają wykryte w ramach powiadomień w systemie RASFF. Sieć stoi na straży unijnego prawa w zakresie łańcucha rolno-żywnościowego. W związku z wykrytym zafałszowaniem sieć FFN podejmuje odpowiednie działania, np. nakłada karę finansową na wszystkie odpowiedzialne podmioty lub zwiększa liczbę inspekcji w danym państwie wysyłającym zafałszowane produkty [Olejnik 2017].

Od 2016 r. sieć FFN jest wspomagana przez informatyczne narzędzie ACC ( $A d$ ministrative Assistance and Cooperation), aby usprawnić współpracę państw członkowskich. ACC umożliwia szybką wymianę informacji między krajami członkowskimi, dzięki czemu mają one możliwość natychmiastowego potwierdzenia podejrzewanego fałszerstwa. Można przyjąć, że systemy RASFF i ACC nawzajem się uzupełniają, ponieważ notyfikacje zgłaszane przez system RASFF mają na celu zapewnienie bezpieczeństwa zdrowotnego żywności i pasz, natomiast informacje dostarczane przez ACC mają zagwarantować bezpieczeństwo ekonomiczne konsumentów żywności. Komisja Europejska zazwyczaj nie ingeruje w informatyczne kontakty między krajami członkowskimi w ramach FFN. Jej rola skupia się właściwe na usprawnieniu tej sieci poprzez obsługę infolinii, przygotowywanie szkoleń oraz monitorowanie prawidłowego działania sieci [Kowalska 2017]. Na rys. 13 przedstawiono grupy produktów, które były zgłaszane do systemu FFN jako produkty zafałszowane. 


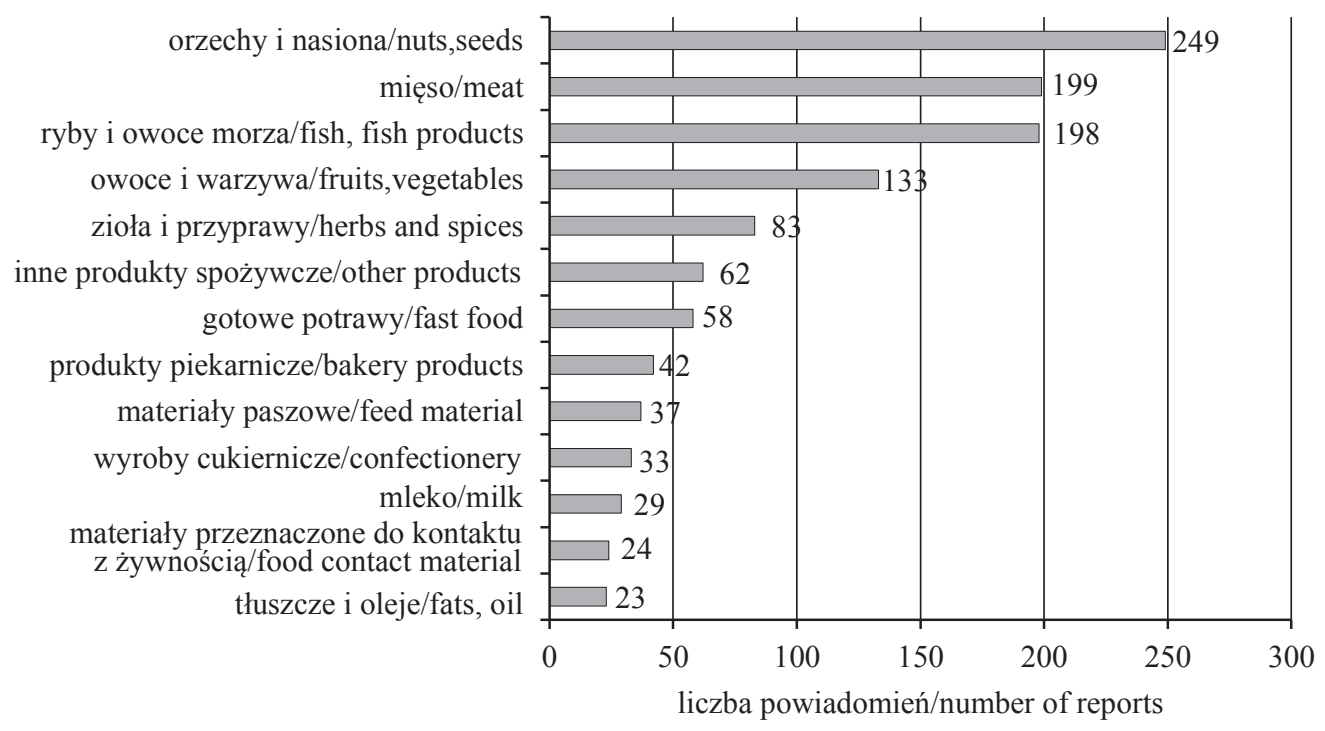

Rys. 13. Liczba zgłoszeń dotyczących zafałszowań produktów żywnościowych w latach 2004-2018

Fig. 13. Number of reports on adulteration of products in 2004-2018

Źródło/Source: opracowanie własne na podstawie/own study on the basis of [The Rapid Alert System for Food and Feed, Annual Report 2017].

Całkowita liczba zgłoszonych do systemu RASFF produktów, które zostały zafałszowane przez producentów w latach 2004-2018, wyniosła 1285. Najczęściej fałszowanymi artykułami spożywczymi były orzechy i nasiona - 249 powiadomien. Niewiele mniej zafałszowań wykryto w wyrobach mięsnych (199 alertów) oraz w rybach i owocach morza (198 alertów). Zafałszowanie żywności zgłaszanej do systemu RASFF dotyczyło najczęściej braku lub niewłaściwych świadectw zdrowia produktów, niezgodności opisu produktu z certyfikatem oraz prób nielegalnego importu od nieautoryzowanego dostawcy.

Ważnym aspektem dotyczącym bezpieczeństwa produktów jest zapobieganie zafałszowaniom szczególnie wyrobów spożywczych. Konsumenci powinni świadomie wybierać produkty, które chcą zakupić. Dlatego też w ramach Systemu Wczesnego Ostrzegania o Niebezpiecznych Produktach i Paszach uruchomiono specjalną funkcję, której celem jest wyeliminowanie problemu fałszowania żywności.

\section{Podsumowanie}

Postęp technologiczny, ciągły rozwój wspólnego rynku Unii Europejskiej i swobodny przepływ towarów zwiększają ryzyko występowania produktów niebezpiecznych dla zdrowia i życia konsumentów. W celu ochrony ich bezpieczeństwa utworzono systemy, które umożliwiają natychmiastową wymianę informacji w zakresie niebez- 
piecznych lub wadliwych produktów. Systemy te pozwalają na szybki kontakt pomiędzy Komisją Europejską i państwami członkowskimi, a także udostępniają informacje o zagrożeniach konsumentom. Do takich mechanizmów szybkiego reagowania zaliczamy system RASFF.

Według danych literaturowych wśród najczęściej występujących zagrożeń żywności wyróżnia się bakterie z grupy Salmonella, pestycydy, metale ciężkie (ołów, kadm i rtęć), azotany i azotyny oraz aflatoksyny. Na podstawie przeprowadzonej analizy można wnioskować, że w przypadku systemu RASFF w latach 2004-2018 odnotowano łącznie 44696 powiadomień, z czego 88\% alertów dotyczyło zagrożeń zidentyfikowanych w żywności. Natomiast najczęściej występującymi zagrożeniami były aflatoksyny występujące w orzechach i nasionach, obecność metali ciężkich w rybach i owocach morza oraz pozostałości pestycydów w owocach i warzywach. W przypadku produktów do kontaktu z żywnością najczęściej występującym zagrożeniem była migracja niebezpiecznych substancji do żywności. Przedstawione wyniki wskazują, że $32 \%$ niebezpiecznych produktów żywnościowych zgłoszonych do systemu RASFF pochodziło z Chin, Turcji, Indii oraz USA.

Z przedstawionych danych wynika, że największą liczbę zafałszowań odnotowano w takich kategoriach produktów żywnościowych, jak: orzechy, nasiona, wyroby mięsne oraz ryby. Nieprawidłowości te były związane z niewłaściwą dokumentacją oraz próbą sprowadzania towaru od nieznanego dostawcy.

Wprowadzenie systemu wczesnego ostrzegania w Unii Europejskiej stało się korzystnym rozwiązaniem wpływającym na poprawę bezpieczeństwa handlu międzynarodowego. System ten jest skutecznym narzędziem stojącym na straży ochrony konsumentów. Wzrastająca z roku na rok liczba powiadomień świadczy o coraz większym zaangażowaniu organów państwowych w dziedzinie bezpieczeństwa produktów oferowanych na wspólnym rynku. Dzięki systemowi RASFF udało się wycofać z rynku wiele niebezpiecznych produktów. Ze względu na wysoką ilość niebezpiecznych produktów pochodzących z państw trzecich ważnym aspektem będzie pogłębianie współpracy pomiędzy nimi a Komisją Europejską. Częste wycofywanie z europejskiego rynku wyrobów pochodzących z państw trzecich może być skuteczną motywacją do poprawy ich jakości i zaostrzenia procedur produkcyjnych. Konieczne jest również regularne dostosowywanie unijnego prawa do pojawiających się nowych zagrożeń.

Podsumowując, System Wczesnego Ostrzegania o Niebezpiecznych Produktach i Paszach odgrywa kluczową rolę w zakresie zapewniania bezpieczeństwa żywności na każdym etapie łańcucha produkcyjnego produktów i żywności poprzez natychmiastową reakcję na wykryte zagrożenie i informowanie wszystkich członków systemów. Każdy niebezpieczny produkt wycofany z rynku może ochronić zdrowie, a także życie wielu konsumentów. Powiadomienia zgłaszane do systemu RASFF powodują, że Komisja Europejska podejmuje odpowiednie kroki w kierunku zmian obowiązujących przepisów. Komisja Europejska na podstawie analizy powiadomień przetwarzanych w systemach wczesnego ostrzegania ustala najczęściej zagrożone 
grupy produktów, dzięki czemu może wprowadzić nowe lub dodatkowe regulacje prawne, które pozwolą na minimalizowanie ryzyka. System RASFF ma duży wpływ na zapobieganie kryzysowi żywnościowemu, a także na zwiększanie zaufania konsumentów do bezpieczeństwa żywności i pasz.

System szybkiego ostrzegania ma również na celu zapobieganie nieuczciwym praktykom stosowanym przez producentów, takim jak fałszowanie żywności. Najczęstszym powodem fałszowania są motywy ekonomiczne. Zachowanie takie jest nieetyczne wobec konsumentów, dlatego też Komisja Europejska wprowadziła rozwiązanie mające przeciwdziałać takim działaniom poprzez uruchomienie specjalnej unijnej sieci, której działania skupiają się na przeciwdziałaniu zafałszowaniu żywności.

\section{Literatura}

Adamczyk D., 2014, Bezpieczeństwo żywnościowe w Unii Europejskiej, Studia Europejskie. Centrum Europejskie Uniwersytetu Warszawskiego, 4(72), s. 213-226.

Dyjak K., Michota-Katulska E., Zegan M., 2017, Pilotażowe badania pozostałości pestycydów w wybranych swieżych ziołach $i$ warzywach przyprawowych zakupionych $w$ krajowych supermarketach, Żywność. Nauka. Technologia. Jakość, 24(1), s. 126-138.

Dyrektywa 2001/95/WE Parlamentu Europejskiego i Rady z dnia 3 grudnia 2001 r. w sprawie ogólnego bezpieczeństwa produktów.

https://ec.europa.eu/food/safety/rasff/reports_publications_en (28.12.2018).

https://ec.europa.eu/food/sites/food/files/safety/docs/rasff_annual_report_2017.pdf (28.12.2018).

https://ec.europa.eu/food/sites/food/files/safety/docs/rasff_annual_report_2011_en.pdf (28.12.2018).

https://ec.europa.eu/food/sites/food/files/safety/docs/rasff_annual_report_2006_en.pdf (28.12.2018).

https://ec.europa.eu/food/sites/food/files/safety/docs/rasff_annual_report_2002_en.pdf (28.12.2018).

https://webgate.ec.europa.eu/rasff-window/portal/?event=searchForm (28.12.2018).

http://www.primoris-lab.com/en/support/legislation/rasff-notifications/ (28.1.2.2018).

Kierczyńska S., 2015, Produkcja i eksport owoców w Polsce w latach 1994-2014, Roczniki Naukowe, t. XVII, z. 5, Poznań.

Kołożyn-Krajewska D., Sikora T., 2010, Zarządzanie bezpieczeństwem żywności. Teoria i praktyka, C.H. Beck, Warszawa.

Komisja Europejska - Zestawienie Informacji, 2017, Pytania i odpowiedzi: System wczesnego ostrzegania o niebezpiecznej żywności i paszach (RASFF), Bruksela, http://europa.eu/rapid/press-release_MEMO-17-2461_pl.htm (28.12.2018).

Kononiuk A., 2018, Wybrane systemy zapewniajace bezpieczeństwo żywności, http://laboratoria.net/ pdf/?get=L2FydHlrdWwvX210ZW0sMjYxOTUscmlkLCxwcmludCwxLHBkZiwxLmh0bWw= (28.12.2018).

Kowalczyk S., 2016, Bezpieczeństwo i jakość żywności, Wydawnictwo Naukowe PWN, Warszawa.

Kowalska A., 2017, Systemy wymiany informacji o oszustwach żywnościowych w Unii Europejskiej, Przedsiębiorczość i Zarządzanie, Lublin, XVIII, z. 9, cz. 1, s. 71-85.

Kowalska M., Mitrosz P., Osytek K., 2018, Wybrane aspekty dotyczace fatszowania żywności, Przemysł Spożywczy, 72(12), s.16-21.

Krzepkowska M., 2015, Powiadomienia w systemie RASFF to źródto informacji przy analizie ryzyka, Przemysł Spożywczy, 69(12), s. 11-14. 
Lagana P., Caruso G., Barone C., Caruso G., Parisi S., Melcarne L., Mazzù F., Della A.S., 2017, Mikrobiologiczne zanieczyszczenia żywności, Wydawnictwo Naukowe PWN, Warszawa.

Ledzion E., Postupolski J., Rybińska K., Kurpińska-Jaworska J., Szczęsna M., Karłowski K., 2010, System RASFF jako element strategii bezpieczeństwa żywności w zakresie mikotoksyn, Bromatologia i Chemia Toksykologiczna, XLIII(4), s. 533-538.

Michalska-Pożoga I., 2013, System RASFF a bezpieczeństwo żywności i żywienia w Unii Europejskiej, Inżynieria Przetwórstwa Spożywczego, 2(6), s. 37-41.

Olejnik J., 2017, Food Fraud. Unia Europejska walczy z fatszowaniem żywności, https://www.foodfakty.pl/ue-walczy-z-falszowaniem-zywnosci (15.02.2019).

Puchlik M., 2011, Zafałszowania żywności, „Fałszerstwom stop”, Szkoła Główna Gospodarstwa Wiejskiego, Warszawa, II edycja konkursu dla studentów na najlepszą pracę pisemną związaną z problematyką fałszerstw pt. „FAŁSZERSTWOM STOP”.

Rozporządzenie Komisji (UE) nr 16/2011 z dnia 10 stycznia 2011 r. ustanawiające środki wykonawcze dla systemu wczesnego ostrzegania o niebezpiecznych produktach żywnościowych i środkach żywienia zwierząt.

Rozporządzenie (WE) nr 178/2002 Parlamentu Europejskiego i Rady z dnia 28 stycznia 2002 r. ustanawiające ogólne zasady i wymagania prawa żywnościowego, powołujące Europejski Urząd ds. Bezpieczeństwa Żywności oraz ustanawiające procedury w zakresie bezpieczeństwa żywności.

Rozporządzenie Komisji (UE) nr 16/2011 z dnia 10 stycznia 2011 r. ustanawiające środki wykonawcze dla systemu wczesnego ostrzegania o niebezpiecznych produktach żywnościowych i środkach żywienia zwierząt.

Sawicki W., 2014, Oszustwa i nadzór w tańcuchu dostaw żywności, Przemysł Spożywczy, 68(2), s. 2-4.

Stankiewicz D., 2012, System wczesnego ostrzegania o niebezpiecznej żywności i paszach RASFF, Analizy BAS, 11(78), s. 1-6.

The Rapid Alert System for Food and Feed, Annual Report 2017.

Wróbel B., 2014, Zagrożenia zwierząt i ludzi toksynami grzybów pleśniowych zawartych $w$ paszach i żywności, Woda-Środowisko-Obszary Wiejskie, 14(3), s. 159-176.

Zadernowski M.R., Zadernowska A., Obiedziński M., Zadernowski R., 2008, HACCP - Katalog zagrożeń biologicznych, fizycznych i chemicznych, Ośrodek Doradztwa i Doskonalenia Kadr Sp. z o.o., Gdańsk. 